\title{
PASSION FOR PAST AND FUNCTIONAL IMPERATIVE: BELGRADE INTERWAR RESIDENTIAL ARCHITECTURE BY ALEKSANDAR DEROKO
}

The name and the achievements of Aleksandar Deroko shine brightly in the constellation of Serbian architectural history. Deroko actively contributed to the Serbian twentieth century architecture as a distinguished professor at the University of Belgrade, a prolific author, esteemed scholar, designer, and a highly driven heritage enthusiast. However, though recognised by his contemporaries and successors alike, Deroko's design activity has not yet been thoroughly examined.

Exploring residential buildings designed for Deroko's Belgrade clientele, this paper widens the knowledge of his architectural production. Deroko's well-known passion for architectural history and extensive research of the Serbian vernacular buildings serve as a starting point for the study of his residential structures in Belgrade. Was Deroko's design process influenced by his deep appreciation for architectural past, and by the results of his findings? Or has he only adopted the formal characteristics of historic styles and vernacular architecture in his work? If so, to what extent? Discussing five structures built in the interwar period - house of Colonel Elezović, the Rakić villa, the Simić villa, the Marinković villa, the Stakić villa and the architect's personal villa - the paper traces transformation of Deroko's architectural inspiration, from typical academic historicist

\section{Milica Madanovic} eclecticism to vernacular construction.

University of Auckland, School of Architecture and Planning 


\section{INTRODUCTION}

Architect, scholar, University lecturer, heritage worker, painter - to list only a few of his interests - Aleksandar Deroko left an indelible mark on the Serbian twentieth century architecture. ${ }^{1}$ His active nature, inquisitive mind, and unpretentiousness resulted in a unique charisma, adored by the students and respected by his peers. Though a number of scholars examined a few of Deroko's most important designs, the architectural production of this versatile and creative individual yet awaits a comprehensive monographic study. Deroko's lesser known buildings remain in the shadow of his other engagements - primarily his successes as an educator and a historian. Focusing on the residential structures designed between the world wars for his Belgrade clientele, this paper contributes to the study of Deroko's design activity.

To set the scenery, the paper will open with a concise consideration of Deroko's life before the World War II (WWII). The second part of the paper focuses on Folklorism - a specific style which emerged in Serbian architecture of the twentieth century. Folklorism is relevant to understanding the methodology behind the designs discussed in this paper. Though he was a productive scholar, Deroko did not write either architectural theory or discuss residential architecture per se. However, he did record his thoughts on this particular building type while analysing vernacular architecture. The third part of the paper discusses Deroko's interwar writings on the Balkan vernacular construction, which served as the main source for interpreting his designs for residential architecture of that period. Finally, the five buildings constructed in the interwar period - the apartment building for Colonel Elezović (1927), the house of Radivoje Marinković (1929), the Simić Villa (1931), the architect's summer house (1936), and the villa of Vlada Stakić (1938) - will be examined in relation to Deroko's ideas about residential architecture.

\section{A SHORT BIOGRAPHICAL NOTE:}

\section{THE CIRCUMSTANCES BEHIND THE DESIGNS}

Though the life path of Aleksandar Deroko was a rich tapestry, a more detailed exploration of its intricate weaving is not necessary for better understanding of the main questions discussed in this paper. ${ }^{2}$ However, it is possible to identify specific circumstances which resonated in his interwar designs. First, Deroko's mechanical engineering studies at the University of Belgrade's Faculty of Technical Sciences. These early interests in construction technologies remained obvious in the entire course of his career. As a researcher of architectural 
heritage, Deroko curiously explored buildings' structural qualities, construction processes, materials, etc. He was fascinated with the vernacular crafts, curiously inspecting and committedly documenting the various technical inventions of the anonymous vernacular creators.

The outbreak of the World War I (WWI) interrupted Deroko's carefree University life in Belgrade. Having fought at Thessaloniki as a fighter pilot, he was sent to recover in Italy and Austria. Deroko enrolled at the Royal Engineering School in Italy, continuing the education he started in Belgrade. However, the year in Rome proved to be a turning point in his career. During his time in the capital of Italy, Deroko discovered history of art and was captivated by the architecture of the "eternal city". Returning to Belgrade, he started studying architecture at the University of Belgrade. Deroko's interest in the history of Serbian and Balkans architecture became obvious well before his graduation in 1926. During the undergraduate studies, he published articles about the medieval architecture. In these years Deroko also worked on the study and protection of architectural heritage as part of a team led by Petar Popović, a respectable medievalist and a professor of architecture at the University of Belgrade. The numerous field trips to the most remote parts of the Balkan Peninsula allowed Deroko to experience first-hand the historic structures, influencing his personal understanding of architecture. Vojislav Korać notes that Deroko's reports were accompanied by his thoughts on the nature of architectural creation. ${ }^{3}$ Exploring medieval sacral architecture, Deroko discovered vernacular. He was instantly attracted to its functionality and adept construction - especially in timber; the longevity of lessons passed on from one generation to another; the boldness and beauty of details. Deroko diligently recorded these research trips, returning with detailed notes, carefully executed drawings, technical analyses, sketches of landscape, etc. Broadly approaching vernacular construction, he was not solely interested in the houses themselves. The curious explorer was attracted to everything related to the construction - auxiliary service buildings, tools, various everyday objects, and ornaments. Rather than studying the past in the positivistic manner of an archaeologist, Deroko strived to understand the complex circumstances influencing the essence and forms of architecture.

Finally, he was personally acquainted with the avant-garde tendencies in art and architecture in Paris. He was sent there in 1926 to study with Professor Gabriel Millet, an esteemed researcher of Byzantine art and architecture, at École de Hautes Études. His friend Rastko Petrović, a Serbian diplomat and poet of avant-garde inclinations, introduced him to the Parisian high society. Among others, Deroko met Guillaume Apollinaire, James Joyce, Saint-John 
Perse, and he was close to the Parisian Dadaist circle. Picasso presented him with one of his paintings, and he was also introduced to Le Corbusier. However, it seems that Deroko remained unimpressed by the new tendencies in art. Zoran Manević notes that, years later, Deroko shared with his students the experience of meeting Le Corbusier in Paris: 'Like every other architect, he would start with form, with the shape, and then cram the functions inside, no matter how they fit'. ${ }^{4}$ Manević also documented the recollection of another Deroko's contemporary. According to this account, Deroko once commented that 'Le Corbusier should have been hanged, in a timely manner, before he infected the world with the idea of the house as a machine for sleeping'.

\section{OUTLINING THE CONTEXT: FOLKLORISM}

Rampant across the Europe since the nineteenth century, the Battle of Styles did not bypass the Balkans. ${ }^{6}$ However, the rules of warfare were slightly different in the pre-WWII Serbia. Broadly speaking, there were three main camps: the academism, the national style, and the Modern Movement. ${ }^{7}$ The first group consisted of architects drawing from various styles of Western architecture from Rundobgenstil to the eclectic Beaux-Arts design principles. The "nationals" tended to look inwardly, devoted to the development of a specific national style of architecture, suitable to the local cultural and geographical context. Similarly to the first group, the proponents of Modernism were searching for an appropriate contemporary architectural expression in the lessons from foreign experiences. Though the discussions were frequent and sometimes rather heated, this classification was rather fluid - the borders between the three were often blurred. As their theoretical thought transformed and matured, respecting the wishes of their clients, or, simply, eager to experiment, the architects often moved between the camps. Deroko's residential architecture was often discussed in the context of Folklorism, a style which bloomed a couple of decades on the Serbian twentieth-century architectural scene. ${ }^{8}$ Folklorism is usually related to a major topic in the Serbian architectural history - the search for national style.

However, it is necessary to add that Folklorism was national in its inspiration rather than in its intention. In its finest theoretical form, it was more regional than national. Its highest achievements, however, remained in the abstract domain of ideas. The two most significant proponents - Branislav Kojić and Deroko - developed the theoretical basis for this manner of architectural expression. ${ }^{9}$ They both assumed that vernacular architecture offered a way out of the conundrum of styles because it was - first and foremost - developed as a response to a functional imperative. It was produced within a specific 
geographical context by anonymous builders primarily focused on its usefulness and perfected throughout the generations. Though they sometimes used vernacular decorative forms in their architectural production, both Kojić and Deroko insisted that the lessons one should take from this rich heritage were the principles. Understanding the principles would, hopefully, lead closer to a "true" architectural expression.

For the majority of architects active in the interwar period Folklorism remained attractive primarily because of its rich repertoire of forms. The main inspiration was the vernacular architectural heritage from Serbia and the Balkans. Definitions of the concept "vernacular architecture" varied. Some maintained that it entailed only village architecture, while others thought that it refers to the built heritage from the sixteenth and eighteenth centuries..$^{10}$ For example, claiming that specific architectural elements were described in Serbian folk poetry, architect Djura Bajaović stressed that the style existed before the Ottoman conquest of the Balkans. He encouraged his colleagues to use the Balkans vernacular buildings as a design inspiration. ${ }^{11}$ Foklorist buildings were mostly highly functional structures devoid of excess architectural ornament. The common decorative means were certain motives from vernacular architecture such as arcaded porches, arches, bay windows; and traditional materials timber, stone, brick, roof tiles, etc. The signature architectural characteristic of the style is certainly dynamic massing of the volumes, highlighted with the contour of a traditionally shaped hip of gabled roofs.

Classified among the most prolific movements in Serbian architecture, ${ }^{12}$ and described as 'more innovative than Modernism because it did not blindly follow the ideas of foreign architects', ${ }^{13}$ Folklorism did not achieve a great success during the phase of its historical manifestation. It did not receive a significant support by the press and remained overlooked by the broader audience. Scholars mostly agreed that the main reason behind the failure of Folklorism was its unsuitability for building types different than the single-family house. Vernacular architecture, the original source of Folklorism, meant free elevations, a garden and a backyard. These characteristics informed the conclusion that the Folklorist manner was more appropriate for the suburbia or the countryside than for the dense urban environments.

Could it be that there were other factors influencing the reserved public attitudes towards Folklorism? For example, the relatively young local urban culture? In the nineteenth century and at the beginning of the twentieth century, a majority of the population was living in the countryside. When the cities began to 
develop, the people migrating from the rural areas tended to fit into the new environment. It seems plausible to assume they were already accustomed to the "picturesque" shapes of vernacular architecture, and that they did not perceive them to be greatly impressive or appealing. Is it possible that as part of their newly acquired urban identity, most of the new citizens were not inclined to deliberately adopt these (former) rural forms?

Furthermore, the liberation wars fought against the Ottoman Empire during the nineteenth century were still fresh in memory. The urban population was probably not ready to accept the architectural forms blooming across the former borders of the Empire and widely associated with the period of foreign rule. The development of the Balkan cities was culturally more inclined towards the countries of Central and Western Europe. Maybe Folklorism failed because, in a way, it was too recent. As perceived in the collective eye, its shapes spoke about the rural and Ottoman legacies of the country which was actively creating a rather different vision for its future. Folklorism did not originate from the officially glorified Serbo-Byzantine heritage, nor was it a product of the Western high culture - as such, it did not attract a broader public support.

Finally, it might be that the reason Folklorism did not succeed was the unobtrusive manner of its protagonists. Neither Kojić nor Deroko propagated their attitudes aggressively. Furthermore, their theory remained inconsistent and unsystematic. Surely, if they developed it further it might have proven to be as influential as the more recent Critical Regionalism? A missed opportunity or a style unsuitable for architectural types other than single-family houses, Folklorism was not a match for the assertive mechanisms of the Modern Movement.

PASSION FOR PAST:

\section{DEROKO'S WRITTINGS AND RESIDENTIAL ARCHITECTURE}

Interestingly enough, for a person who had so much to say about architecture - and did so quite often, as illustrated by the impressive list of his titles Deroko did not discuss his work extensively. Zoran Jovanović, the author of the most detailed examination of the architect's life and work to date, noted that Deroko valued only 'the dearest of his executed designs'. ${ }^{14}$ Unfortunately, Jovanović did not specify which designs Deroko held dearest. Maybe Deroko's silence about his own architectural pieces stemmed from his appreciation of the 'anonymous folk builder', a person he often praised in his ponderings on vernacular architecture. This was the silent protagonist of the discipline, one 
who expressed his intimate architectural ideas not through words - for he might have not been able to communicate his notions as a formally educated architect - but through his craft. His name would not be remembered in history, only his work. And, alas, his work was prevalently not constructed in solid materials. Underappreciated by the general public, vernacular architecture was disappearing across the Balkans. A passionate researcher and historian of the vernacular architecture, Deroko fought to preserve it.

How did he fight to preserve vernacular architecture? Primarily through a scholarly project of research. Deroko strongly opposed the formation of an official architectural school which would, in some way, try to resurrect the vernacular construction. He maintained that artificially infusing life force into the folk architecture would be impossible, 'for it is impossible to stop the stream of development. ${ }^{15}$ It would be degrading to this rich architectural heritage. In a genuine historicist manner, Deroko maintained that different historical periods existed within specific sets of conditions. The dominant architectural style was an expression of those conditions and that period. 'Different times, under different conditions, produced at least to a certain extent different style. ${ }^{16}$ Therefore, an attempt to reproduce past architectural elements in contemporary production would be futile and anachronistic. Deroko was not a revivalist.

One could be tempted to assume that Deroko's ideas could be grouped within the intellectual domain of the Arts and Crafts Movement, which peaked between 1880s and 1920s. Indeed, at first sight, the similarities are overwhelming. ${ }^{17}$ Similarly to the proponents of the Arts and Crafts, Deroko praised the ingeniousness of the vernacular craft. In fact, he hired craftsmen for the construction of a couple of his designs, and, to an extent, insisted on the application of the traditional tools and methods. Furthermore, he valued and used the traditional materials, and designed pieces inspired by vernacular forms. However, there were three fundamental differences between Deroko's views and those propadated by the Arts and Crafts Movement. First of all, Deroko was against the establishment of schools, workshops, and movements. Furthermore, though he appreciated the diverse folk inventiveness, and was intimately familiar with their craft, Deroko did not oppose the industrial development. He did not side with the Modernists in their adoration of the Machine, either. He simply did not fight against the technological progress: 'The old age was the age of the crafts... The time of the crafts has come to an end. The age of the industry begins. ${ }^{\prime 18}$ The statement neither praises nor accuses. Stating the obvious facts, it was an impartial acceptance of the inevitable. Finally, Deroko's architectural thought was not coloured by moralising or activist tendencies. 
He did not conceive of architecture in terms of "honesty" or "truth". He did not insist or theorise on the construction of "honest" architecture "true" to its material, structure, and function. Deroko did possess a deep appreciation for functionality of the vernacular architecture. However, he pragmatically interpreted this quality as an adept response to the human needs, rather than as an abstract, moral imperative.

This insistence upon the design functionality brought Deroko closer to the ideas of the Modern Movement. Similarly to the Modernist views, he was critical of contemporary architectural production, commenting that 'today, we do not have any particular architectural style. ${ }^{19}$ Furthermore, Deroko wrote against the obstinate emphasis on architectural beauty: 'in order for a house to be beautiful, it sometimes becomes almost unusable or, at least, uncomfortable. ${ }^{20}$ Deroko praised the Modern architecture for its rejection of the abstract, futile aesthetics. On a different occasion, he described the ornament as useless. ${ }^{21}$ However, somewhat a Romantic in his aesthetic inclinations, he strongly opposed the famous Modernist notion of a house as a machine for living. Decades before Kenneth Frampton wrote his Critical Regionalism, Deroko sharply criticised the Modernist architecture. ${ }^{22} \mathrm{He}$ objected to the uniformity of the Modernist forms and their insensitivity for the local context. In his opinion, the universal design formula championed by the Modern Movement was not appropriate for different regions of the world. The value should be placed on the geographical context of the building; the emphasis put on topography and climate.

If the answer for contemporary architecture did not lie in revivalism, a continuance on the past styles, or the solutions proposed by the Modernist circles, where, in Deroko's opinion does it lie? More important for the particular focus of this paper - what was crucial for the design methodology of residential architecture? Truth be told, he did not offer a definite solution. His theoretical views remained scattered and required further development. However, his writing offered an insight into his way of thinking. In an article on the Balkans' vernacular architecture, Deroko divided local architecture into two groups:

1. the official - sacral architecture characterised by strong foreign borrowings;

2. vernacular architecture - the people did not borrow, rather 'they built in the way they could and felt like. ${ }^{23}$

In an attempt to explain the nature of the way in which people built, Deroko drew upon a long, sometimes conflicted tradition of architectural theory, which started with Vitruvius and reached its peak in the work of Gottfried Semper. ${ }^{24}$ 
Deroko maintained that the most basic forms of architecture - the primitive hut, the cave and the tent - were influenced by the geographical context and the way of life. In his opinion, the clearest expression of this basic architectural logic was found in vernacular architecture.

According to Deroko, the planning aspect of design process depends on the three basic factors. Firstly, the practical living needs. Architecture, in its essence, was a human protection from the elements, animals, and other people. It was supposed to provide the most comfortable living and working environment. Hence, the way of living and working directly influenced the design layout. Construction, on the other hand, depended mostly on the available building materials. In addition to the previously discussed planning and construction, the final form of a building was influenced by the third factor - climate conditions.

In one of his earliest papers on vernacular construction, Deroko added two more sources of influences for the development of architectural shapes, which he abandoned in his later writings. However, they will be included here because, dated in 1940s, they undoubtedly informed the thinking behind his interwar architectural production. The fourth factor which influenced the shape of the vernacular architecture was 'that which the people themselves carried within their soul. ${ }^{25}$ That is the taste of the anonymous folk craftsmen-builder. The core historicist concept of individuality and an ethnic, supranational pride resonated in the elaboration of the fourth point. ${ }^{26}$ 'The last one, the taste, [the people] brought with them during the settling of the Balkans from its ancient homeland, behind the Carpathian Mountains... They knew how to build both beautifully and distinctively... [The first Slavs] knew, or at least, felt, the art and the beautiful, though "beautiful" was not sought for the sake of itself, but resulted from the practical forms. ${ }^{, 27}$ Some scholars commented on the role Folklorism played in the construction of a homogenous Yugoslav national identity. ${ }^{28}$ The previous quote fits perfectly into that line of interpretation. However, one must wonder about Deroko's intention. Could it be that he did not write deliberately to contribute to the dispersion of Yugoslav national ideas, but instead primarily with the category of ethnos in mind?

Lastly, shifting from conceptualism to a more Universalist viewpoint, Deroko came close to Laugier's efforts to define architecture 'as the material art of construction' ${ }^{29}$ one which is self-referential. Deroko stressed that the shape and the appearance of a vernacular building depended on the way materials were fitted together. Regardless of the type of material - whether it was timber, stone, or brick - it could be laid in vertical lines. This manner of construction was 
used for various types of structures - from timber chalets in the mountain to the highly developed, complex Hagia Sophia in Constantinople. Deroko then slightly changed the interpretation of the classical post and lintel structural type. He explained that the other manner of the use of the materials entailed two vertical columns which carried the gabled roof. The spaces between the vertical carriers were filled with any type of lighter material resulting in walls. Parthenon, and all of the Greek temples were built in this manner, as were the south Serbian vernacular buildings.

Deroko was somewhat contradictory in his conclusion of this theoretical piece, stating that these principles were contained within one people, one tribe, or one region since their conception. Whatever other circumstances influenced the way they built their homes, the shapes of those constructions are always primarily dependent on that essential architectural conception. All of the basic architectural principles of a people are visible in the construction of vernacular buildings.

Deroko held vernacular architecture in high esteem. He maintained that architecture primarily needed to appropriately respond to a geographical context, and insisted that vernacular construction did precisely that. However, he did not suggest that the forms and the appearance of contemporary buildings should employ the folk motives. What is implied here is that a modern architect should learn from them and adopt the lessons they were silently offering. So, what were the forms and appearances of vernacular architecture? Deroko offered a classification of vernacular types, based on the systematisation of a vast built heritage he examined during his field trips. The entire Balkan vernacular architecture was divided in two basic groups with regards to the construction method:

1. The ancient chalet, in the mountain areas;

2. "Bondruk" architecture, in the valleys. ${ }^{30}$

To these two fundamental types he added smaller groups:

1. The most primitive houses, built mostly in the mountains of vegetation, most notably using tree branches and straw;

2. The Šumadija type is related to the "bondruk" type of construction, with distinctive and recognisable arched porches;

3. The stone masonry along the coast of the Adriatic Sea - the stone was used because of the lack of timber;

4. The stone masonry in the Zagorje region, the so-called Arnaut towers. The stone was used as a means of reinforcement. Timber was plentiful in this area and sometimes used for the upper storeys; 


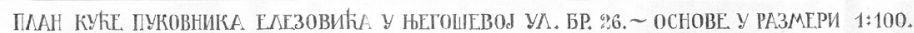
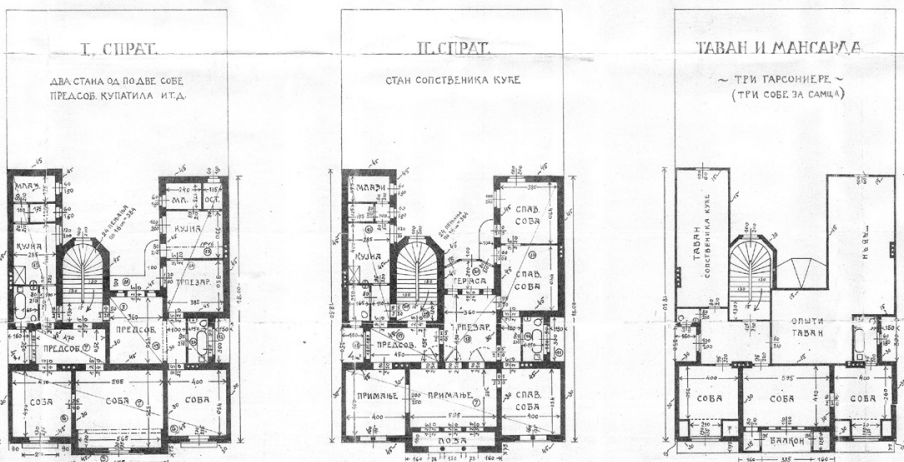

GEOTPAA JVKA 192Z:

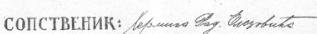

TPOІЕКТТАТTИ: a

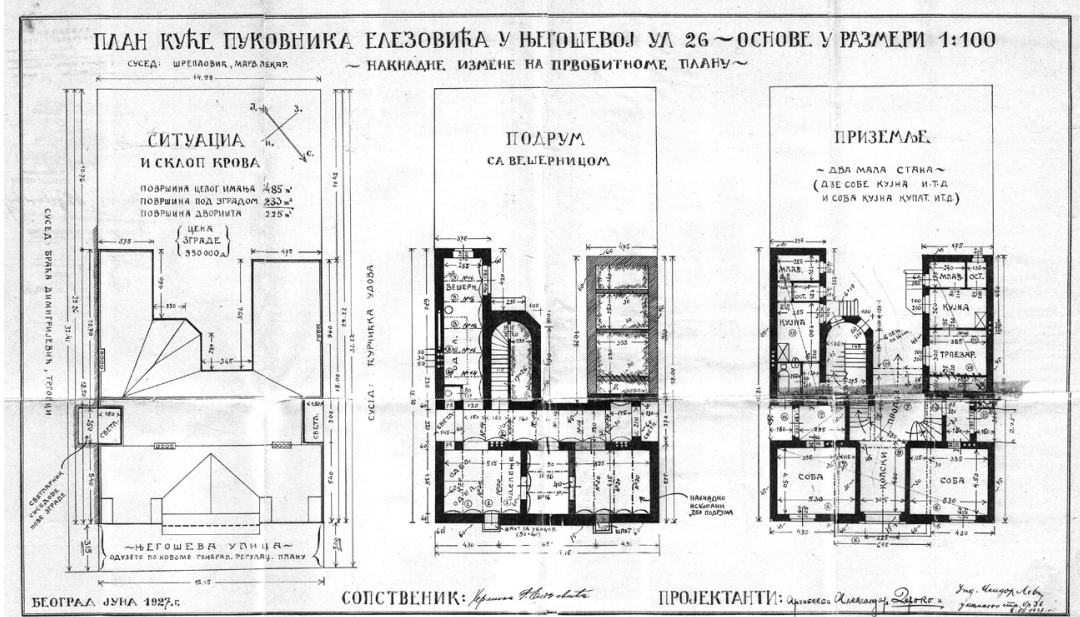

Fig. 1 -2. The floor plans for the Colonel Elezović apartment building. (IAB F. XI-30-1927) 
5. The German type, north of the Sava and Danube rivers, with streetfacing tympanum of elaborate Baroque form and decoration.

Deroko discussed the materials and planning of different types of construction method, primarily depending on climate conditions, topography and the human way of life. He did not dwell on the style of ornaments, though he took note of them (i.e. the "German" type). He was principally interested in the functionality of designs. Throughout his writings he warned against the tendency to subordinate the functionality of planning to the beauty of a building. However, he did not dismiss the need for aesthetics in architecture. In fact, he stressed that architecture must be "spiritually" pleasing. It had to be designed in a manner satisfying for both physical and psychological human needs. ${ }^{31}$ A house should be oriented towards a view, and, whenever possible, come with a beautifully decorated garden. This was especially significant for villas: 'it is a luxurious, not only practical building, but not luxurious in the sense of overwhelming amount of abstract ornament, but only if attention is paid to luxury and the usefulness of "beautiful". ${ }^{32} \mathrm{He}$ deemed vernacular architecture to be beautiful, with its tall roofs, bay windows, arched porches, vivid colours, and naive baroque volutes. The carved ceilings, the wide eaves, and chimneys conveyed the folk sculptural conceptions. A wooden cross, branching like a treetop of a mounting pine, a village gravestone, a wooden carriage, pottery, furniture, etc. expressed a people's artistic feeling alike. ${ }^{33}$ Deroko related the beauty of vernacular ornament with functionality; in his opinion it primarily stemmed from its careful planning, cost-effectiveness and unpretentiousness.

\section{ARCHITECTURAL HANDWRITING:}

\section{DEROKO'S RESIDENTIAL BUILDINGS IN BELGRADE}

The first significant residential building Deroko designed for a client in Belgrade was the multi-storey apartment building for Colonel Elezović on 26 Njegoševa Street. ${ }^{34}$ Constructed in the dense urban scenery of the central Belgrade, the building was set on the street regulation line, and laterally leaned on the neighbouring structures. The construction of the building started on 18 July 1927 and finished on 1 April $1928 .{ }^{35}$ Officially approved by the Construction Board on 26 October 1927, minor changes were made to the original designs during the construction process. The building had a basement, a ground floor, and three storeys while the structure was reinforced concrete with walls made of bricks and mortar. Covered stone stairs, placed next to the courtyard façade were the point of vertical circulation. The symmetrical U-shaped floor plans 

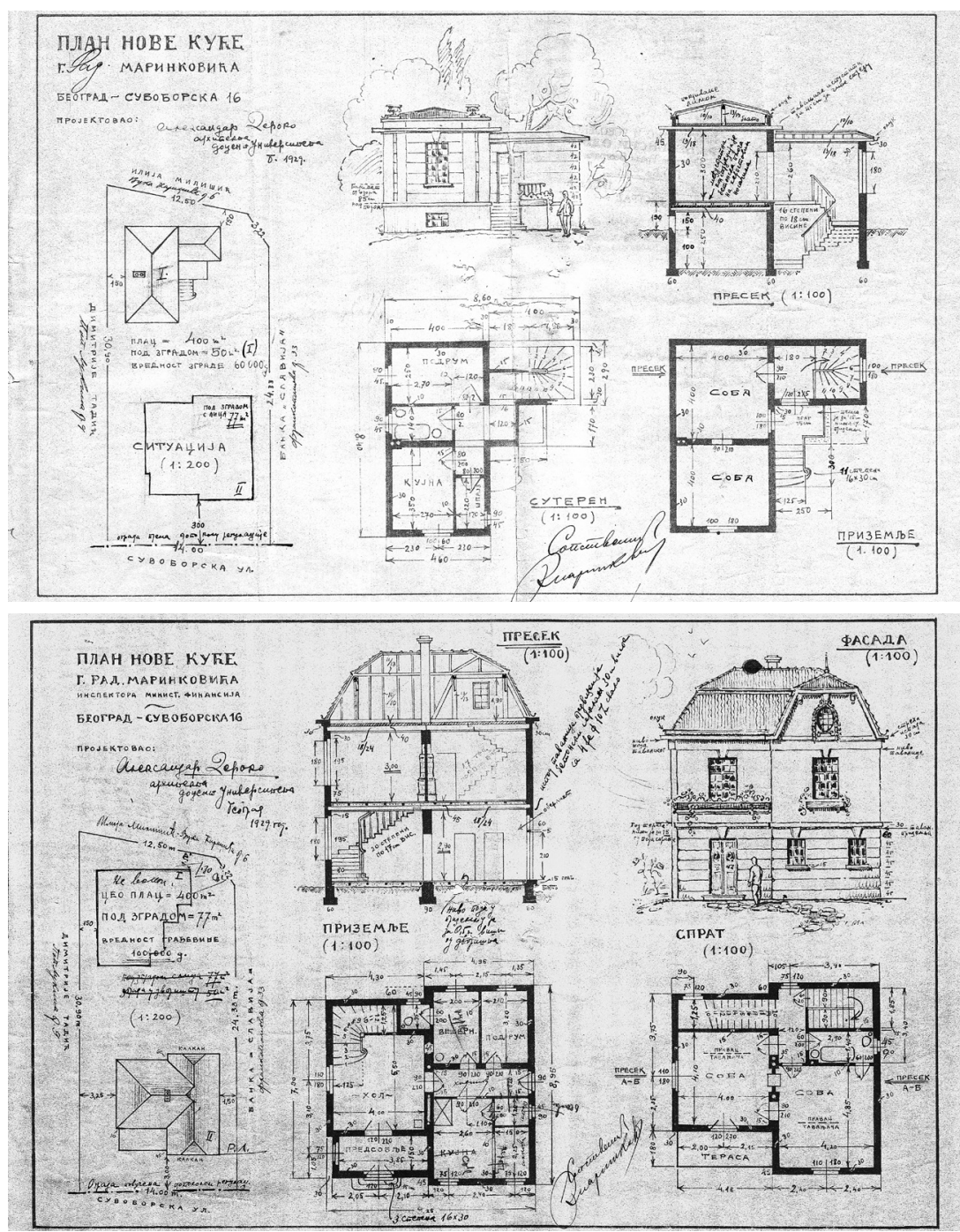

Fig. 3 - 4. Designs for the Marinković Villa (IAB F. VIII-14-1929) 
followed a typical Beaux-Arts design layout (Figures 1, 2). A laundry room was in the basement while two smaller, one bedroom apartments for rent were placed on the ground floor. The first floor had one larger apartment in the eastern wing, and a smaller one in the western one. The piano nobile was elevated to the second floor, which the landlord kept entirely for himself. The spacious reception rooms were situated behind the street façade. Service rooms - a kitchen, a small pantry, and the servant's bedroom - were in the eastern wing of the building. The dining room, the bedrooms and the bathroom were placed on the opposite side. Finally, three studios with the shared bathroom facilities, the landlord's and general storage units, were at the last level of the building.

The façade of the building is perhaps the most commented one amongst all of Deroko's residential achievements. Almost every scholar who wrote about his design included the Colonel Elezović's apartment building. And rightly so. The building won him an award in 1930 for the most beautiful façade by the Architects' Club and its patron Dušan Tomić. ${ }^{36}$ As an expressive, handsome mixture of the Serbian-Byzantine style and Viennese secession, this multistorey building was described as Deroko's most successful piece of residential architecture. The jury noted that the arcade is "characterised with a simplicity of means and correctly interpreted spirit of a genuine naiveté of our ancient builders' ${ }^{37}$ Decades later, scholars agreed that Deroko did not simply copy motives from architectural history. Approaching the architectural past as a scholar and an erudite, he searched for the aesthetic lessons, the principles of the bygone ages. He incorporated these in his own design methodology. Interpreted in that way, Colonel Elezović's building should be understood not as a compilation, but as a transposition of the medieval Serbian and Byzantine architectural spirit. ${ }^{38}$

Designed three years after his graduation, upon his return from Paris, and before he started his research travels across the Balkans that would bring him closer to the lessons of the vernacular architecture, Deroko designed two buildings in the eclectic Beaux-Arts style for Radivoje Marinković, a prominent inspector at the Ministry for Finances ${ }^{39}$ Both buildings were constructed on 16 Suvoborska Street, on a rectangular, relatively small lot of land spanning 400 square meters between April and July 1929. Both were set as far as possible from the site's borders, creating coulisses for the central garden space. The vegetation depicted in both designs can be interpreted as a hint of the importance Deroko would place on the relation between architecture and nature. 


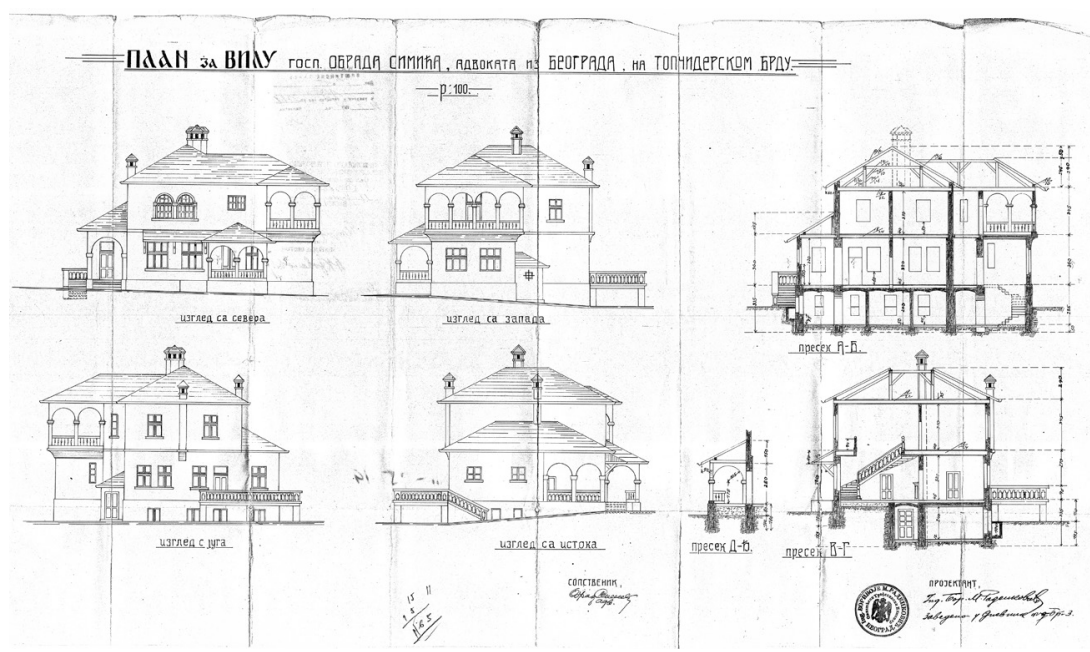

Fig. 5. Designs for the old mansion at the Simić Estate (IAB f. XII-25-1927)

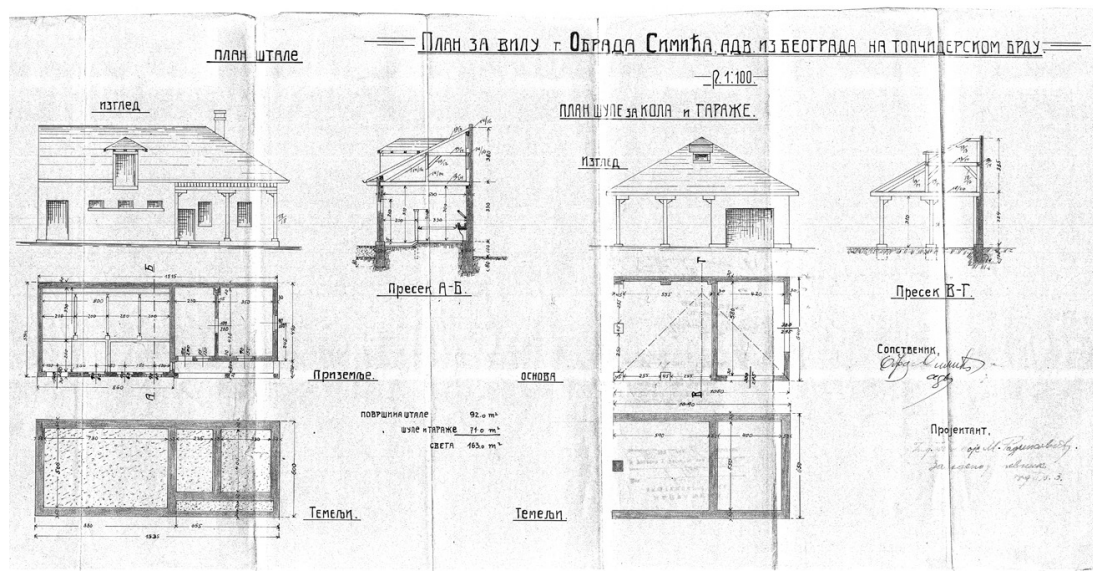

Fig. 6. The floor plans for the Colonel Elezović apartment building. (IAB F. XI-30-1927) 
The house closer to the street was more spacious ( 77 square meters). Facing the street, the entrance led into a small vestibule (Figure 3). From there, one would proceed to a spacious foyer, with elegant stone stairs, and service rooms on the right-hand side. The two rooms, and a bathroom were on the first floor. The house had a small attic with a mansard roof. The smaller house (42.5 square meters) was placed deeper inside the lot (Figure 4). From a small porch, a visitor would step into an entrance hall with stairs leading to the basement. Two rooms were on the first floor, while the service rooms were partially underground. Both buildings were of elegant proportions, with subtle Neo-Baroque ornamentation and rusticated ground floor.

Stylistically completely different were the designs made for Obrad Simić, the famous Belgrade lawyer, in 1931..$^{40}$ Both buildings reflected Deroko's knowledge acquired during his exploration of Serbian architectural past. Deroko designed a new villa, built on the foundation of an older barn. At the same time he adapted an old garage for servants' quarters. Constructed on the foundations of the pre-existing structures, they cannot be used as an example of Deroko's site planning. The buildings were free standing, aligned, and placed deeper into the large site, behind the main villa.

The works on both buildings were executed concurrently between 25 May 1931 and 22 December $1931 .^{41}$ The designs showing the concept for the older villa at the Simić estate are kept at the Historical Archives of Belgrade. Signed by the civil engineer Borivoje Radenković, the old mansion was constructed in 1927 for Ljuba Janković, a director at a bank (Figure 5). ${ }^{42}$ The freestanding single-storeyed structure was accompanied by a barn and a small garage. The three buildings were freestanding. The mansion's prominent characteristic were the dynamic massing and picturesque contour of hip roofs of different heights. Chimney caps, arched porches, a double arched window at the first, and a balustrade at the spacious southern terrace on the groundfloor were employed as the envelope's decorative elements. The Simić villa was an appealing architectural piece in the vernacular "bondruk" style, with playful shapes which communicated with the surrounding landscape. Placed on the same axis, behind the main building, the smaller buildings were harmoniously incorporated into the architectural syntax of the estate (Figure 6). The simple shapes of the barn and the garage with hip roofs and colonnaded porches balanced out the dynamic envelope of the villa, and complimented the back garden in an unobtrusive manner. 


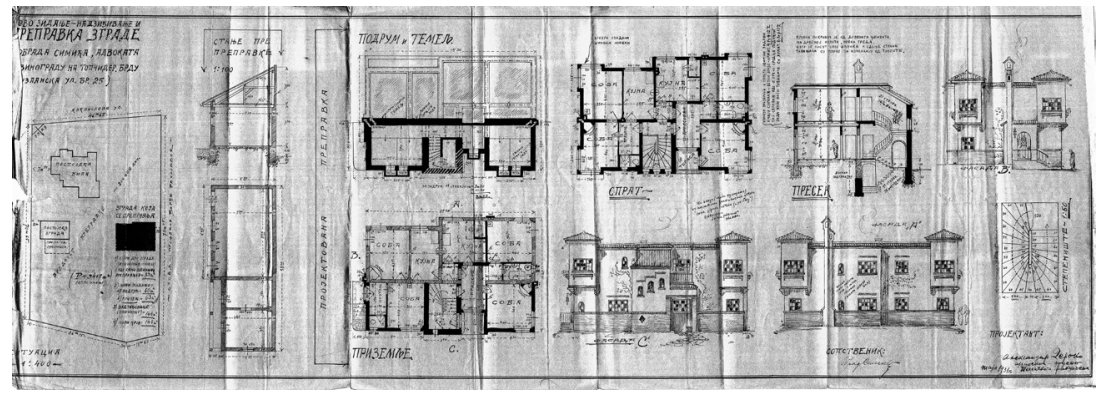

Fig. 7. The Simić Villa (Simic IAB IX-22-1931)

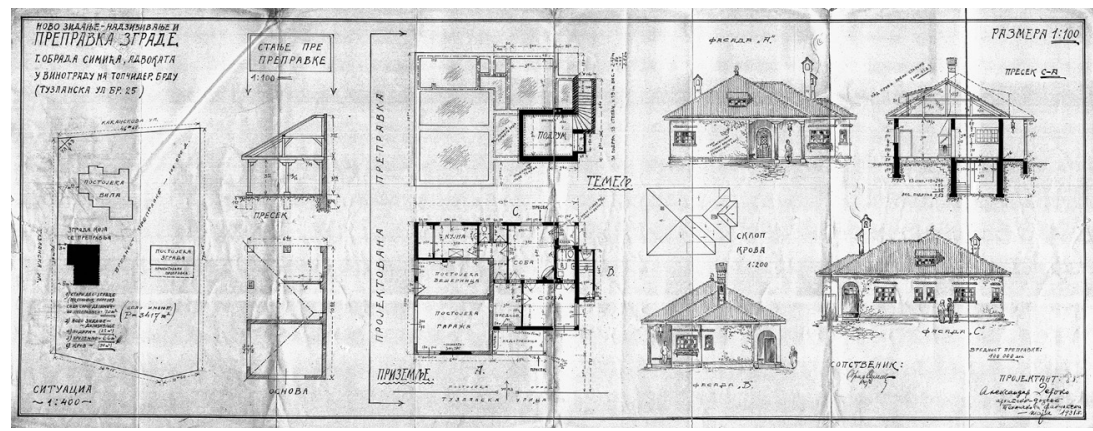

Fig. 8. Designs for the smaller house on the Simić estate (IAB IX-22-1931) 
The old barn was adapted to a mansion (Figure 7). The older 83-square meterstructure was significantly enlarged. The new building had three levels - the basement ( 80 square meters), the ground floor (145 square meters) and the first floor (also 145 square meters). The floors were vertically connected by a stairwell placed behind the main façade. The two habitable floors had a similar layout. Each floor had two self-contained units with separate entrances. However, the units were connected through the centrally-located kitchens. Every unit had two rooms - the larger one, was presumably a living room, with a fireplace, and an individual toilet.

In terms of form, the exterior of the building did not resemble the other two structures on the estate. The original plans show dominantly horizontal massing with small rectangular corner towers. Resting on top of the decorative consoles and overhanging the ground floor, the towers were the main vertical accents of the envelope. The central segment of the main façade was picturesque, with the dynamically resolved, protruded stairwell and entrance envelope, covered with roofs of different heights. Deroko wrote the instructions for rough plaster finish of the façades, which was then to be sprayed with green colour. Climbing plants were also introduced as a decorative element of the façades. The roofs were gently titled, with recognisable vernacular chimney caps. Simple, small aperture, lack of ornamentation, massing, roof contour, and climbing vegetation, radiated the feel of vernacular architecture - a picturesque combination of the Mediterranean and bondruk styles.

Deroko altered the appearance of the villa during its construction. He introduced the tall central tower for the stairwell, which became the main vertical focus of the envelope. The chimneys were abandoned, and a sun clock added, which was typical for the façades of Mediterranean towns. The result was a heavier structure more closely associated with the forms of medieval ramparts than vernacular architecture. This decision should be questioned bearing in mind the forms of the other buildings built on the same type of estates. The playful vernacular forms would certainly correspond better with the built context than the stricter, more massive volumes reminiscent of a medieval fortress. Furthermore, using the small-sized openings and omitting decks or balconies, Deroko did not open his façades towards the surrounding garden.

The smaller building, constructed on the foundations of the old garage was almost doubled in size, with 63 square meters added to the old building of 70 square meters. The new building, designed for domestic workers, had a more spacious basement and a L-shaped habitable spaces (Figure 8). The house 
ii)

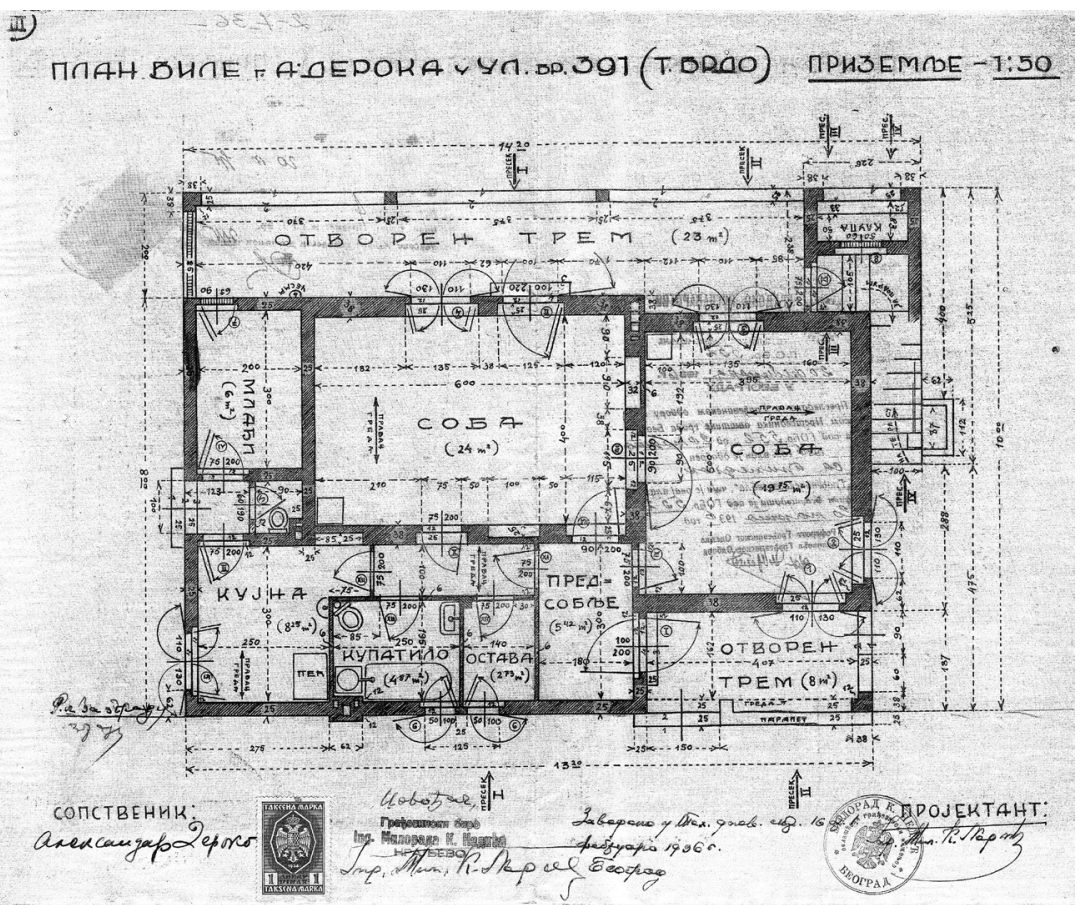

Fig. 9. Floorplan for the Deroko house (IAB f. 2-7-1936)

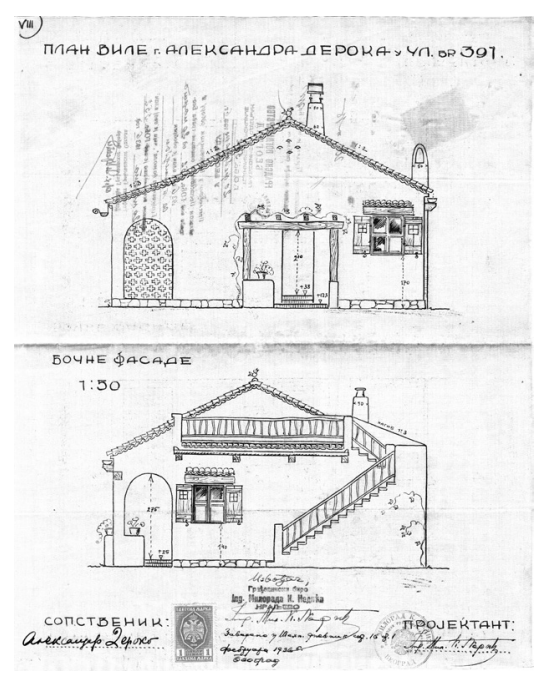

Fig. 10. Design for lateral facades of the Deroko house (IAB f. 2-7-1936)

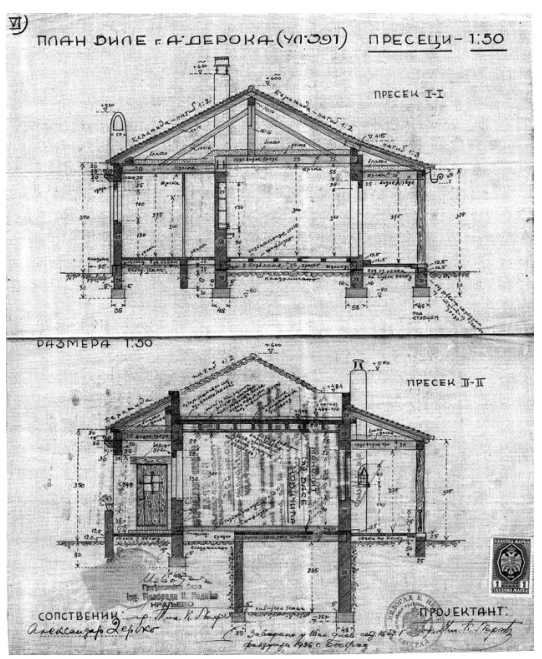

Fig. 11. Cross-section of the Deroko house (IAB f. 2-7-1936) 
had two rooms, a kitchen, and a bathroom. The pre-existing garage and the laundry room were incorporated into the new layout. Deroko used the dynamic contour of the hip roofs with decorative chimneys and the columned porches to establish a connection with the older villa. On the other hand, the shape of the aperture, the rough plaster finish, sprayed with reddish-yellow colour, and the climbing plants communicated with the new villa. Heavily inspired by the forms of vernacular architecture, dynamic masses of the house would effectively serve as a bridge between the two larger structures. However, similarly to the larger structure, a lack of larger decks disabled a communication between the building's interior and the site. In his later designs, Deroko would use larger decks and balconies, attempting to create a stronger connection between the architecture and the surrounding nature.

Perhaps the most discussed Deroko's project was his own house on 3 Jovana Danića Street. The 137-square meter-building was constructed between 21 March and 2 May $1936 .{ }^{43}$ According to a report from the Historical Archives of Belgrade the building's value, without the sewerage, was 80,000 dinars. The house had three access points. From the street, a modestly shaped open porch lead to a small entrance hall. From there, one could access the service spaces - a storage, a bathroom and a kitchen - on the left-hand side of the house, and to the right, a room which led to the second room (Figure 9). Both rooms opened to a spacious back porch, facing the garden. The third was the servant's entry, placed on the lateral façade. A small covered porch led to the servant's bedroom, a small toilet, and the kitchen. Directly inspired by the vernacular practice, Deroko placed the stairs outside of the house, leaning on the façade. Interestingly, the stairs - the main decorative motive of the lateral façade - led to a terrace at the attic level. However, as stated in the technical report, the attic was not to be used, and in fact, was inaccessible (Figure 10). ${ }^{44}$ This decision is somewhat inconsistent with Deroko's insistence on functionality and cost effectiveness of architecture.

The envelope was imagined modestly, strongly inspired by the vernacular construction. All four façades open to the exterior. The two sides facing away from the street had open platforms, along their entire lengths - the shorter, lateral one a balcony, and the longer one a deck. The façades were decorated with different materials - a plinth of crushed stone, timber beams, and bricks; climbing plants; used ladders instead of balustrades; barrels for the collection of rainwater; wooden gutters, etc. It was noted that Deroko erected his summer house not only inspired by the vernacular forms, but with the use of vernacular construction process itself. Though historiography claimed that the house 
was built solely with traditional tools and materials, it seems that this was a slight exaggeration. Having in mind that concrete - the so-called "monolith" by engineer Vasa Novičić - was structurally employed, and Deroko's positive views of new techniques and materials, it might be more precise to say that the traditional construction process was indeed applied, but not at the cost of the quality and solidity of the structure (Figure 11). It was interesting that Deroko physically incorporated vernacular architecture into his new home. The house was built with materials from demolished folk buildings - timber beams, roof tiles with still attached old houseleeks, wooden gutters, ladders instead of fences - were all collected from households located across the Balkans. Whether these pieces were a medium for transposition of ideas of the "nameless folk builders" touched by the spirit of craft that Deroko valued so highly, or simply souvenirs from architect's numerous journeys, remains open for discussion. Bogdan Bogdanović interpreted the construction of this house as an eco-artistic endeavour, an architectural assemblage, even as a product of a modern artistic simulation game ${ }^{45}$ It was, indeed, a genuine avant-garde experiment; so called architecture without architects.

The house of the prominent lawyer Vlada Stakić is so far the last known design made by Deroko for a residential building in Belgrade. Unfortunately, no archival material is available on the structure at the Historical Archives of Belgrade - it was a brief site visit and previously published photographs that made this discussion possible. ${ }^{46}$ The villa was built in 1937, at the intersection of Tolstoy and Miloša Savčića streets. The photographs show that the building follows a U-shaped layout. Covered with an open gable roof, the transverse parts of the building flanked the central arched porch. The long, back part of the structure was covered with a hip roof. The villa followed the line of inspiration with the Mediterranean vernacular architecture. The foot of the building was cladded with stone, and the upper sections were roughly plastered. The façades were once again devoid of any excess ornamentation and were communicating with the surrounding site area through generously-sized porches and balconies. The whiteness of the envelope was contrasted with the consoles under the mullioned windows, brick chimneys, and Deroko's personal signature decoration made from the roof tiles placed above the windows, applied in all of his residential designs.

The previously discussed structures illustrated the transformations of Deroko's aesthetic inclinations in residential architecture. His Belgrade residential oeuvre could be divided in two phases - the academic (1920s) and the vernacular (1930s). The buildings Deroko designed during the 1920s were heavily 
influenced by his formal education, informed by the educated taste of a BeauxArts trained architect. Capturing Deroko's fascination with the vernacular architecture, the 1930s structures, on the other hand, captured a more personal design approach. However, certain characteristics were present, in varying degrees in all of the buildings. Perhaps the most evident constant in Deroko's design methodology was his relation to ornament. Bogdan Bogdanović noted that Deroko's approach to ornament 'was neither emotional nor accidental' ${ }^{47}$ According to Bogdanović, Deroko analytically treated the essence of ornament, 'and dignity of this universal human language made him careful about its morphology and syntax'. ${ }^{48}$ Indeed, though residential buildings Deroko designed varied stylistically, they reflected his mastery of ornament. The façades were characterised with high aesthetic appeal, accomplished through a skilful compilation of architectural elements and lack of excess ornamentation. The planning also revealed Deroko's attitudes toward the most important qualities of architectural design to certain extent in different structures. He did not subordinate the functionality of the floorplans to the typical BeauxArts demand for symmetry. Though he did not experiment with the open floor concept, Deroko also restrained himself from wasting too much space on hallways. All of the designs are characterised with logical division of spaces and overall functionality of the solutions. Deroko wrote about the importance of orientation and views for the satisfaction of human psychological needs in the early 1940s. The individual residential structures demonstrate that Deroko's methodology for the establishment of relations between the architecture and the surrounding nature developed in time, before his writing on the topic. Compared with the earliest designs for the Marinković and Simić villas, the later projects such as the one for the lawyer Stakić and for his own house, clearly show more success in opening the architecture up to the site.

\section{CONCLUSION}

Dejan Medaković notes that Deroko had a lot of respect for, and a deep emotional response to, all of the creations of the human spirit, and above all, architecture. Similarly, Deroko's writings remained a unique mixture of the scholarship, warmth and feelings, revealing the intimate artistic experience of their author. ${ }^{49}$ Deroko did not defend or impose his architectural beliefs. His intention was not to formulate a consistent architectural theory. Accordingly, his thoughts on architecture were not expressed immediately, but as a secondary layer of Deroko's writings primarily focused on topics from the domain of history. 
It is possible to condense the several main demands architecture had to meet in order to be deemed valuable from Deroko's analysis of vernacular architecture. First of all, it had to be functional. This meant that planning needed to be practically developed to satisfy human needs for comfortable living and working environment. Furthermore, the floorplan layout, construction, and architectural forms needed to correlate to the geographical context - the terrain and, above everything else, climate conditions. Deroko often wrote about the materiality of architecture. He stressed that the use of specific materials depended on their availability. Devoted to functionalism, he did not insist upon the use of traditional materials - architecture should follow the technological progress and employ the most efficient of solutions. Architecture also needed to satisfy human psychological needs. This was achieved not through the excess use of the needless and often quite expensive ornamentation. Rather, a proper orientation of the building, the opening of façades, correlation with the surrounding nature, and the maximum use of the potential of views were crucial. For Deroko, aesthetical qualities of an architectural piece originated in its functionality; he equated beauty with usefulness.

In his own residential designs Deroko managed to achieve the high standards he discussed throughout his writings to a varying degree. Similarly to his theoretical ponderings, it seems that if only he had developed his design methodology a bit further - in evolving his theory and applying it in his designs systematically - his villas might have taken a rightful place amongst the most successful achievements of Serbian architectural history. However, as was the case with his architectural theory, this most probably was not Deroko's intention. The architect was more likely focused on the production of functional spaces that would prove to be comfortable for his clients. With the exception of his own summer house, he did not use his residential projects as a testing ground for his architectural beliefs. However, their unostentatious functionality and engaging formal solutions undoubtedly contributed to the urban scenery of Belgrade and deserved the appropriate attention by scholar and the general public. 

RZZZSK, 1991); Slobodan Bogunović, Arhitektonska enciklopedija Beograda. II: Arhitekti (Beograd: Beogradska knjiga, 2005, 750-757); Zoran Manević, Leksikon neimara, Beograd: Gradjevinska knjiga, 2008, 89-96; Dejan Medaković, “Aleksandar Deroko," Sveske DIUS 19 (1988): 3-5; Vojislav Korać, “Aleksandar Deroko - skica za portet,” Glasnik DKS 15 (1991): 241242; Legende beogradskog Univerziteta: Aleksandar Deroko 1894-1988. Katalog izložbe (Beograd: UBSM, 2008); Bogdan Bogdanović, “Aleksandar Deroko," in Umetnici akademici 1968-1978 (Beograd: SANU, 1981), 207-213; Aleksandar Kadijević, Jedan vek traženja nacionalnog stila u srpskoj arhitekturi (sredina XIX - sredina XX veka) (Beograd: GK, 2007), 300-302; Aleksandra Ilijevski, "Status i značaj gradjevina Aleksandra Deroka izvedenih u starom jezgru Beograda," Stara gradska jezgra i istorijske urbane celine: problem i mogućnosti očuvanja i upravljanja, (Beograd: ZZZSKGB, 2013), 327-341.

A detailed biography was presented in: Zoran Jovanović, Aleksandar Deroko, 9-19. 
A reliable introductory overview: Robin Middleton and David Watkin, Neoclassical and $19^{\text {th }}$ Century Architecture (New York: Abrams, 1980).

On academism: Aleksandar Kadijević, Estetika arhitekture akademizma (XIX-XX vek) (Beograd: Gradjevinska knjiga, 2005); on national style: Aleksandar Kadijević, Jedan vek traženja nacionalnog stila u srpskoj arhitekturi (sredina XIX - sredina XX veka) (Beograd: Gradjevinska knjiga, 2007); on Modernism: Zoran Manević, Srpska arhitektura 1900-1970 (Beograd: Muzej savremene umetnosti, 1972).

On Folklorism: Aleksandar Kadijević, "Folklorni smer nacionalnog stila u srpskoj medjuratnoj arhitekturi," in Jedan vek traženja, 321-330; Manević, Novija srpska arhitektura 1900-1970, 2021; Vladana Putnik, "Folklorizam u arhitekturi Beograda (1918-1950)," in GGB, LVII (Beograd: Muzej grada Beograda), 175-210.

On Kojić see: Snežana Toševa, Branislav Kojić (Beograd: Gradjevinska knjiga, 1998).

Nadežda Pešić-Maksimović, "Stvaralaštvo arhitekata podstaknuto lucima sa moravske kuće," in Saopštenja XXXIV (Beograd: RZZZSK, 2003), 403-419.

Djura Bajalović, “Ka starom srpskom stilu,” BON (December 1932): 769.

Ljiljana Miletić Abramović, Arhitekture rezidencija i vila Beograda 1830-2000 (Beograd: Karić fondacija, 2002), 341.

Putnik, “Folklorizam u arhitekturi Beograda (1918-1950)," 204.

Jovanović, Aleksandar Deroko, 63.

Aleksandar Deroko, "Folklor u arhitekturi kod nas se više ne obnavlja," Telegram (21. 9. 1939): 7.

Aleksandar Deroko, "Naš nacionalni stil u arhitekturi," Vreme (6. 1. 1941), s.p.

More on A \& C: Peter Davey, Arts and Crafts Architecture (London: Phaidon, 1995).

Aleksandar Deroko, "Naša folklorna arhitektura," Umetnički pregled 3 (1940): 78-79.

Aleksandar Deroko, "Naš nacionalni stil u arhitekturi," Vreme (6. 1. 1941), s.p.

Aleksandar Deroko, “Estetika kuće u polju,” Umetnički pregled 1 (1938): 142.

Deroko, "Naša folklorna arhitektura," 143.

Kenneth Frampton, "Towards a Critical Regionalism: Six Points for an Architecture of Resistance," in The Anti-Aesthetic. Essays on Postmodern Culture, ed. by Hal Foster (Seattle: Bay Press 1983), 16-30.

Deroko, "Naša folklorna arhitektura," 72.

On Gottfried Semper see: Mari Hvattum, Gottfried Semper and the Problem of Historicism (Cambridge: Cambridge University Press, 2004).

Deroko, "Naša folklorna arhitektura," 73.

For a concise, comprehensive classification of numerous historicist viewpoints see: Andrew Reynolds, "What is Historicism?," International Studies in the Philosophy of Science 13/3 (1999): 275-287.

Deroko, "Naša folklorna arhitektura," 73.

Aleksandar Ignjatović, "Izmedju zezla i ključa: nacionalni identitet i arhitektonsko nasledje Beograda i Srbije u XIX i prvoj polovini XX veka," Nasledje 9 (2008): 54-55.

Caroline van Eck, Organicism in Nineteenth-Century Architecture: An Inquiry into its Theoretical and Philosophical Background (Amsterdam: Architectura \& Natura, 1994), 96.

Deroko, "Estetika kuće," 143.

Ibid. 
Aleksandar Deroko, "Folklor u arhitekturi kod nas se više ne obnavlja," 7.

Ksenija Ćirić, Kuća pukovnika Elezovića (Beograd: ZZZSKGB, 2013).

Official Statement by Aleksandar Deroko, 25 December 1928, Folder XI-30-1927, Historical Archives of Belgrade.

“Četiri nagradjene kuće u Beogradu,” Politika (24. 1. 1930): 7.

Bogunović, Arhitektonska enciklopedija, 753.

Ilijevski, "Status i značaj," 332-333.

Report by the Belgrade City Construction Department, 8 April 1929, Folder VIII-14-1928, Historical Archives of Belgrade.

Obrad Simić bought the lot, with three existing buildings on 19 March 1920 for 160.000 dinars: Proof of Property Ownership, 19 March 1928, Folder IX-22-1931, Historical Archives of Belgrade.

Report by the Belgrade City Construction Department, 24 December 1931, Folder IX-22-1931, Historical Archives of Belgrade.

Proof of Property Ownership, 5 March 1927, Folder IX-22-1931, Historical Archives of Belgrade; Design Projects Signed by Borivoje Radenkovic, Folder IX-22-1931, Historical Archives of Belgrade.

Report by the Belgrade City Construction Department, 14 August 1936, Folder f2-7-1936, Historical Archives of Belgrade.

Technical Description by Aleksandar Deroko, February 1936, Folder f2-7-1936, Historical Archives of Belgrade.

Bogdanović, “Aleksandar Deroko,” 211.

Jovanović, Aleksandar Deroko, 86; Bogunović, Arhitektonska enciklopedija Beograda, 754; Pešić-Maksimović, "Stvaralaštvo arhitekata podstaknuto lucima sa moravske kuće," 407; Putnik, "Folklorizam u arhitekturi Beograda (1918-1950)," 187.

Bogdanović, “Aleksandar Deroko,” 211.

Bogdanović, “Aleksandar Deroko,” 211.

Medaković, “Aleksandar Deroko,” 3. 
Bajalović, Djura. "Ka starom srpskom stilu.” BON (December, 1932): 769.

Bogdanović, Bogdan. “Aleksandar Deroko.” In Umetnici akademici 1968-1978, 207-213. Beograd: SANU, 1981.

Bogunović, Slobodan. Arhitektonska enciklopedija Beograda. II: Arhitekti, 750-757. Beograd: Beogradska knjiga, 2005.

“Četiri nagradjene kuće u Beogradu.” Politika (24. 1. 1930): 7.

Ćirić, Ksenija. Kuća pukovnika Elezovića. Beograd: ZZZSKGB, 2013.

Davey, Peter. Arts and Crafts Architecture. London: Phaidon, 1995.

Deroko, Aleksandar. "Estetika kuće u polju.” Umetnički pregled 1 (1938): 142-143.

Deroko, Aleksandar. "Folklor u arhitekturi kod nas se više ne obnavlja." Telegram, 21. 9. 1939, 7.

Deroko, Aleksandar. "Naša folklorna arhitektura." Umetnički pregled 3 (1940): 78-79.

Deroko, Aleksandar. "Naš nacionalni stil u arhitekturi." Vreme (6. 1. 1941)., s.p.

Eck, Caroline van. Organicism in Nineteenth-Century Architecture: An Inquiry into its Theoretical and Philosophical Background. Amsterdam: Architectura \& Natura, 1994.

Frampton, Kenneth. "Towards a Critical Regionalism: Six Points for an Architecture of Resistance.” In The Anti-Aesthetic. Essays on Postmodern Culture, edited by Hal Foster, 16-30. Seattle: Bay Press 1983.

Hvattum, Mari. Gottfried Semper and the Problem of Historicism. Cambridge: Cambridhe University Press, 2004.

Ignjatović, Aleksandar. "Izmedju zezla i ključa: nacionalni identitet i arhitektonsko nasledje Beograda i Srbije u XIX i prvoj polovini XX veka.” Nasledje 9 (2008): 54-55.

Ilijevski, Aleksandra. "Status i značaj gradjevina Aleksandra Deroka izvedenih u starom jezgru Beograda.” In Stara gradska jezgra i istorijske urbane celine: problem i mogućnosti očuvanja $i$ upravljanja, 327-341. Beograd: ZZZSKGB, 2013.

Jovanović, Zoran. Aleksandar Deroko. Beograd: RZZZSK, 1991.

Kadijević, Aleksandar. Estetika arhitekture akademizma (XIX-XX vek). Beograd: Gradjevinska knjiga, 2005.

Kadijević, Aleksandar. Jedan vek traženja nacionalnog stila u srpskoj arhitekturi (sredina XIXsredina XX veka). Beograd: GK, 2007.

Korać, Vojislav. “Aleksandar Deroko - skica za portet.” Glasnik DKS 15 (1991): 241-242.

Legende beogradskog Univerziteta: Aleksandar Deroko 1894-1988. Katalog izložbe, Beograd: UBSM, 2004.

Manević, Zoran. Srpska arhitektura 1900-1970. Beograd: Muzej savremene umetnosti, 1972.

Manević, Zoran. Leksikon neimara, 89-96. Beograd: Gradjevinska knjiga, 2008.

Medaković, Dejan. “Aleksandar Deroko.” Sveske DIUS 19 (1988): 3-5.

Reynolds, Andrew. "What is Historicism?." International Studies in the Philosophy of Science 13/3 (1999): 275-287.

Middleton, Robin and David Watkin. Neoclassical and 19th Century Architecture. New York: Abrams, 1980.

Miletić Abramović, Ljiljana. Arhitekture rezidencija i vila Beograda 1830-2000. Beograd: Karić fondacija, 2002. 
Pešić-Maksimović, Nadežda. "Stvaralaštvo arhitekata podstaknuto lucima sa moravske kuće." Saopštenja XXXIV (2003): 403-419.

Putnik, Vladana. "Folklorizam u arhitekturi Beograda (1918-1950)." In GGB LVII, 175-210. Beograd: Muzej grada Beograda.

Toševa, Snežana. Branislav Kojić. Beograd: Gradjevinska knjiga, 1998. 